\section{Hvem har rettigheter til gener?}

\section{Morten Walløe Tvedt}

Norsk genressursrett

Rettslige betingelser for innovasjon innenfor bio- og genteknologi. 380 s. Oslo: Cappelen akademisk, 2010. Pris NOK 498

ISBN 978-82-02-30585-7

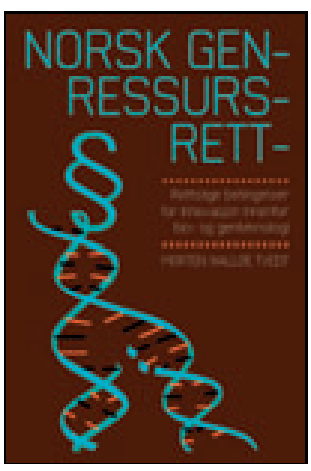

Denne utgivelsen er en samlet fremstilling av norsk genressursrett, med søkelys på jus og rettsregler som har betydning for gener, genetiske ressurser, bioteknologi og genteknologi i Norge. Målgruppen er et stort publikum, både jurister og andre som arbeider med genetisk og biologisk materiale i Norge, alt fra fiskeoppdrett til husdyravl. Forfatteren, jurist og seniorforsker på Fridtjof Nansens Institutt, tar ikke opp spørsmål knyttet til menneskelig genetisk materiale, men genetisk materiale fra alle andre typer organismer. Innholdet er basert på forskningsprosjekter som forfatteren har deltatt i de siste ti årene.

Boken er inndelt i 13 kapitler, med en rekke underkapitler, som omhandler bl.a. gener og DNA som basis for verdiskapning, hvilke lover, konvensjoner og traktater, nasjonalt og internasjonalt, som regulerer norske genressurser, rettslig regulering av genetisk materiale som innføres til Norge, patentrett og internasjonal rettsutvikling. Siste kapittel består av referanser og et stikkordregister. I tillegg er det rikelig med fotnoter i hvert kapittel. Boken er ikke innbundet, men har ryddig layout og et didaktisk språk.

Feltet er stort og uoversiktlig, men forfatteren gjør her et godt forsøk på å skaffe en oversikt over rettskildebildet, både nasjonalt og internasjonalt. Norge har spilt en viktig rolle innenfor genressursretten, bl.a. i etableringen av et system som skal bidra til en åpen utveksling av plantegenetisk materiale. Et mye omtalt initiativ er de nylig opprettede frølagrene på Svalbard.

Det skjer i dag en rivende utvikling på alle områder hvor man benytter genetisk materiale. Dette er utfordrende for lovgivningen nasjonalt og globalt. Internasjonal genressursrett har delvis vokst frem fra kunnskapsendringer og endringer i teknologi. Både internasjonale forpliktelser og nasjonale rettsregler er delvis blitt til med utgangspunkt i plantesektoren. Det gjelder også deler av domspraksis innen patentretten. Forfatteren påpeker Norges unike sjanse, som en nasjon med høyt kunnskapsnivå og tilgang på kapital, til å skape et kunnskapssamfunn basert på bio- og genteknologi. Fornuftig rettslig regulering av genetiske ressurser er et viktig virkemiddel. Det er behov for å diskutere hvilke rammebetingelser de enkelte sektorene som bruker genetisk materiale, har bruk for. I lovendringene som har skjedd de siste årene, har man ikke vært nok opptatt av å utrede hvilke rettslige betingelser som skal til for å fremme bioteknologisk forskning og utvikling i Norge.

Har dette noen betydning for medisinsk forskning? Når det gjelder kommersialisering av humant biologisk materiale, dvs. også humane gener, setter helseforskningsloven (2008) klare grenser, $\S 8$ : «Kommersiell utnyttelse av forskningsdeltakere, humant biologisk materiale og helseopplysninger som sådan er forbudt.» Men når det gjelder bearbeidede organer og vev, vil man kunne oppnå patent, såfremt grunnvilkårene i patentloven er oppfylt. Men det er ikke bare humane gener som er av betydning for medisinsk forskning. I Verdens helseorganisasjon ble spørsmål om en standardavtale for utveksling av patogener behandlet i 2010, dvs. utveksling av sykdomsfremkallende organismer til bruk i medisinsk forskning og utvikling. Syntetisk biologi er en kraftig effektivisering av genteknologien. Det er nå mulig å syntetisere lange DNA-tråder, og i mai 2010 klarte gruppen til Craig Venter å overføre et komplett syntetisk arvestoff til en beslektet bakteriecelle og erstattet cellens eget DNA (1). Hans gruppe har allerede søkt om flere patenter, noe som er kontroversielt idet det kan hindre andre i å bruke de samme teknikkene. Syntetisk biologi kan gi muligheten til bl.a. å modifisere celler til å produsere nye medikamenter. Genressursretten er under stadig utvikling, og det er et gjennomgående behov for å tilpasse genressursretten til aktuelle sektorbehov, som innen helse, hvor genetisk materiale kan brukes til å fremskaffe nye vaksiner og medikamenter.
Dette er ingen bok som kan leses i et strekk, til det er den for tung. Men som oppslagsbok har forfatteren langt på vei lyktes med å gjøre en bok for hovedsakelig jurister til interessant lesning for en ikke-jurist med translasjonsforskning og biobankvirksomhet som arbeidsfelt. Tema er svært aktuelt i en tid hvor politikere og sykehusledere har innovasjon høyt oppe på dagsorden.

\section{Wenche Reed}

Stab forskning, innovasjon og utdanning

Oslo universitetssykehus

\section{Litteratur}

1. Gibson DG, Glass JI, Lartigue $C$ et al. Creation of a bacterial cell controlled by a chemically synthesized genome. Science 2010; 329: 52-6.

\section{Fortsatt god, men ujevn oppdatering om akuttmedisin}

Torben Callesen, Kristian Antonsen, red. Den akutte patient

2. utg. 392 s, tab, ill. København: Munksgaard Danmark, 2010. Pris DKK 548

ISBN 978-87-628-0777-8

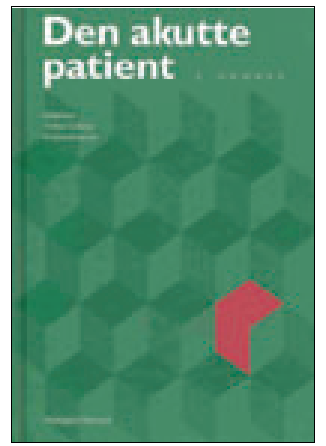

De fleste bøker om akuttmedisin er på engelsk, noe som ikke representerer en stor utfordring for de fleste, men kombinasjonen av fremmedspråk og andre behandlingstradisjoner enn det vi er vant til, kan være et problem. En annen utfordring er at man tradisjonelt presenterer diagnosene først, i stedet for å ta utgangspunkt i de symptomene og tegnene som den enkelte akuttpasient frembyr. Det er derfor gledelig at våre danske kolleger nå har oppdatert sin fem år gamle lærebok i akuttmedisin, som, da den ble utgitt, representerte en forholdsvis ny tilnærming til temaet.

45 forfattere har bidratt i de samme 25 kapitlene som sist, pluss at det er et nytt kapittel om den akutte pasienten i allmennpraksis. Omfanget har økt med 45 sider, og prisen har økt med $42 \%$. Oppbyggingen er logisk, med en generell innføring i ABC- 
prinsippene for akuttbehandling og overvåking. Deretter følger håndtering av problemer fra de ulike organsystemene. En detalj er tekstbokser med viktige kliniske poenger, noe som både øker lesbarheten og motivasjonen. I de fleste kapitlene sier forfatterne hva som er viktigst behandling henholdsvis de første fem minuttene, den første timen og det første døgnet. Det gjør boken praktisk.

Layouten er bra og teksten lettlest. Kapitlene er symptomorientert og rikt illustrert med så vel kasuistikker som gode figurer, fargebilder og tabeller med behagelig bruk av fargeraster. Trykkvaliteten er også god.

Dog synes det litt tilfeldig hva man har valgt å illustrere med respektive foto og strektegning, for eksempel figur 2.12, som er et unødvendig fargebilde av en gutt med «brillekateter» for oksygentilførsel. Redaktørene burde ha hatt en mer tydelig strategi for hvilke forhold man skal illustrere, slik at kontinuerlig overtrykk (continuous positive airway pressure, CPAP) ble illustrert, i stedet for minst tre illustrasjoner av lumbalpunksjon. Kapitlet om bildediagnostikk hadde således fortjent større bilder med bedre gråtoner. Det er mange gode algoritmer, men noen er litt uoversiktlige, som for hypotermipasienter i figur 24.2. Litteraturhenvisningene er noe oppdatert, men fortsatt dominert av litt eldre publikasjoner. Flere Internett-ressurser hadde vært ønskelig.

En del av teksten fortjener noen kommentarer. C-clamp er neppe den mest effektive eller vanlige behandlingen av ustabile bekkenbrudd, og man kan diskutere hvor praktisk nyttig ATLS' (Advanced Trauma and Life Support) klassifikasjon av blødning egentlig er. Hyperventilering anbefales ved tegn på forhøyet intrakranielt trykk. Man beskriver intraossøs tilgang, men nevner ikke de siste hjelpemidlene som er tilgjengelig her. Dermatomkartet (figur 13.2) har ikke S1 avmerket, og på det arrangerte bildet av akutt intubasjon av en skadet pasient (figur 12.1) vises ikke hansker, tilgjengelig sug, mandreng i tube, cuff-sprøyte og kapnograf. Alt dette er essensielt for en sikker prosedyre.

Man kan videre argumentere for at det hos en pasient med redusert bevissthet (Glasgow Coma Score <9) ikke er viktigst med intubasjon og sedasjon, men å sikre luftveier og oksygenering/ventilasjon.

I kapitlet om hjertestans bruker man hyppig ordet hjertemassasje. Den korrekte betegnelsen er brystkompresjon. Her burde man også benyttet et bilde av en defibrillator med klebeelektroder, som i figur 4.2. Jeg savner også utfyllende retningslinjer for behandling etter vellykket gjenoppliving. Videre er det ikke i henhold til vanlige behandlingsretningslinjer å anbefale antihistaminer og steroider før væsketerapi ved anafylaksi (tabell 8.4). Kapitlet om akuttmedisin i allmennpraksis er bra, men tra- keotomi og nåletrakeotomi er vel mindre aktuelt enn intravenøs tilgang (tabell 26.3).

Avslutningsvis mener jeg at betydningen av de såkalte ikke-tekniske ferdighetene $i$ akuttmedisinen hadde fortjent noen sider. Totalt sett mener jeg likevel at denne boken fortsatt er passende lektyre for norske medisinstudenter, og deler av den passer også for ambulansepersonell som ønsker å lære mer.

\section{Guttorm Brattebø}

Akuttmedisinsk seksjon

Kirurgisk serviceklinikk

Haukeland universitetssykehus

\section{Nyttig om AD/HD}

Stein Lunde

\section{Hypersuper - Superhyper}

218 s, ill. Stavanger: Hertervig Forlag, 2010. Pris NOK 250

ISBN 978-82-8216-128-2

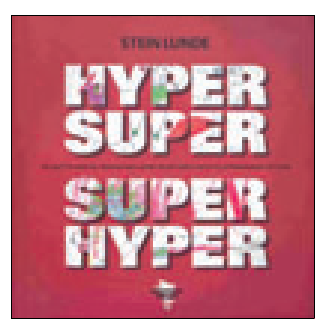

Stein Lunde er klinisk pedagog med lang erfaring innenfor barne- og ungdomspsykiatrien. Han ønsker å beskrive sitt arbeid med barn og ungdom med diagnosen Attention Deficit/Hyperactivity Disorder (AD/HD) for på den måten å øke forståelsen for konsekvenser av $\mathrm{AD} / \mathrm{HD}$ i hverdagen. Målgruppen er fagfolk innenfor helsevesen, sosialvesen og skole, samt foreldre og andre som møter barn og ungdom med $\mathrm{AD} / \mathrm{HD}$.

Boken har tre hovedkapitler som heter Stillasbygging, Den individuelle kontakten og Samarbeid. Hvert av de tre kapitlene er delt opp i underkapitler, de fleste på to-fem sider. Forfatteren dekker ulike områder i de enkelte underkapitlene, hvorav enkelte er dialoger med barn og ungdom, illustrert med tegninger. Noen omhandler teoretiske og praktiske modeller for terapeutisk arbeid, mens andre tar for seg diagnoser, bruk av medikamentell behandling og organisering av spesialisthelsetjenesten.

Lunde er på sitt beste når han beskriver praktisk arbeid med barn og foreldre. I sine beskrivelser av samtaler og praktisk tilrettelegging gir han eksempler på forståelse og handling som kan hjelpe barnet til å fungere bedre i hverdagen. Lunde har også arbeidet med bl.a. musikk og teater og bringer dette inn i terapeutisk arbeid.

Når forfatteren tar for seg områder som årsaker til $\mathrm{AD} / \mathrm{HD}$, nevrobiologiske aspekter, diagnoser og psykofarmakologisk behandling, blir han periodevis ganske vinglete i sine synspunkter. Det hadde kanskje vært bedre å samle dette fagstoffet, slik at han bedre kunne utdypet viktige spørsmål, som tiltak i skolen for barn med innlæringsvansker, bruk av medikamentell behandling og organisering av spesialisthelsetjenesten.

Leseren får ingen samlet oversikt over diagnostikk og behandling av AD/HD.

Boken egner seg derfor best for fagfolk som kjenner feltet fra før. I så måte kan forfatterens beskrivelser gi ideer til arbeidsmåter med barn, ungdom og familier.

\section{Pål Zeiner}

Enhet forskning psykisk helse barn og ungdom Avdeling for forskning og utvikling Klinikk psykisk helse og avhengighet Oslo universitetssykehus

\section{Populistisk om psykiatritjenesten}

Trond F. Aarre

Manifest for psykisk helsevern

231 s. Oslo: Universitetsforlaget, 2010.

Pris NOK 329

ISBN 978-82-15-01744-0

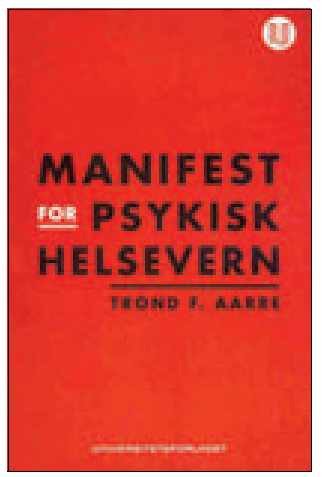

Forfatteren er spesialist i psykiatri og har i mange år arbeidet som avdelingssjef ved Nordfjord psykiatrisenter. På omslaget står det at boken er et skarpt innlegg i den viktige debatten om den tradisjonelle psykiatrien som

i stadig mindre grad svarer til forventningene fra myndighetene og brukerorganisasjonene. De tre delene har følgende titler: Hvordan bør vi noerme oss psykiske

lidelser? Hva er det pasientene trenger?

Et husholdningsperspektiv.

Aarre medgir at den tradisjonelle medisinske modellen har sin plass i behandlingen av alvorlig syke pasienter, der korrekt diagnostikk og målrettet behandling er avgjørende for et gunstig forløp. Imidlertid anser han denne modellen som uhensiktsmessig for de fleste problemene man møter i psykisk helsevern, fordi den fører til sentralisering, er lite tjenlig for brukerne og uforholdsmessig kostbar. Han er glad for at mange nye yrkesgrupper som statsvitere, jurister og økonomer har funnet veien til helsetjenesten fordi de kan tilføre nye perspektiver. Han mener at de fleste tjenestene kan leveres desentralisert og uten innleggelse i døgnavdelinger, at spesialisthelsetjenesten $i$ dag behandler for mange med ukompliserte tilstander og at den holder for lenge på pasientene. Videre skriver han at for mange får psykoterapi og medikamentell behandling uten effekt. De burde heller 